\title{
Enhanced clean-up of lead-contaminated alluvial soil through Chrysanthemum indicum $\mathrm{L}$.
}

\author{
D. Mani $\cdot$ C. Kumar $\cdot$ N. K. Patel $\cdot$ D. Sivakumar
}

Received: 23 March 2013/Revised: 26 October 2013/Accepted: 18 December 2013/Published online: 9 January 2014

(C) Islamic Azad University (IAU) 2013

\begin{abstract}
The natural potential of Chrysanthemum indicum L. for the clean-up of lead-contaminated soil was investigated under pot experiment. Maximum applied lead (at $50 \mathrm{mg} / \mathrm{kg}$ ) caused significant reduction in the plant height $(31.71 \%)$, root length $(31.15 \%)$ and dry biomass (32.71 and $41.25 \%$ for root and shoot, respectively); however, minimum applied lead (at $10 \mathrm{mg} / \mathrm{kg}$ ) promoted the growth of plants to some extent, over the respective control pots. Lead concentration in the tissues followed the order as root $>$ shoot $>$ flower. The combinatorial treatment $T_{16}(50 \mathrm{mg} / \mathrm{kg} \mathrm{Pb}, 0.8 \mathrm{~g} / \mathrm{kg}$ elemental sulphur and $6 \mathrm{~g} / \mathrm{kg}$ vermicompost) caused maximum concentration of lead in root, shoot and flower up to the extent of 43.58, 22.45 and $9.62 \mathrm{mg} / \mathrm{kg}$, respectively, leading to the maximum bioaccumulation factor (0.38). However, the combinatorial treatment $T_{4}$ (sulphur and vermicompost) showed maximum translocation factor $(0.63)$ and $T_{12}(20 \mathrm{mg} / \mathrm{kg}$ lead, $0.8 \mathrm{~g} / \mathrm{kg}$ elemental sulphur and $6 \mathrm{~g} / \mathrm{kg}$ vermicompost) produced maximum remediation ratio $(0.153)$. The combinatorial treatments under lead-contaminated $(10-50 \mathrm{mg} /$ $\mathrm{kg}$ ) soils showed higher remediation efficiency indicating enhanced clean-up of the aforesaid soils through $C$. indicum L. Applied lead ( $>20 \mathrm{mg} / \mathrm{kg}$ ) altered the chlorophyll-
\end{abstract}

D. Mani - C. Kumar · N. K. Patel

Department of Chemistry, Sheila Dhar Institute of Soil Science, University of Allahabad, Allahabad 211002, India

\section{Kumar $(\square)$}

The National Academy of Sciences, India, 5 Lajpatrai Road, Allahabad 211002, UP, India

e-mail: chitranjan.alld@gmail.com

D. Sivakumar

Department of Civil Engineering, Vel Tech High Tech Dr. Rangarajan Dr. Sakunthala Engineering College, Avadi, Chennai 600 062, Tamil Nadu, India a, chlorophyll-b and carotenoid contents of the plants. Hence, the authors conclude that a non-edible ornamental plant, C. indicum L., is preferred to be safely grown in moderately lead-contaminated soils along with application of elemental sulphur and vermicompost, which will boost the photosynthetic pigments of the plants, leading to enhanced clean-up of the lead-contaminated soil.

Keywords Bioaccumulation and translocation factors . Chrysanthemum indicum L. · Lead phytoremediation . Photosynthetic pigments · Remediation efficiency $\cdot$ Sulphur and vermicompost

\section{Introduction}

Metals are the most prevalent forms in the environment, and their remediation in soils is a difficult task. Soil pollution by heavy metals is a global environmental problem as it has affected about 235 million hectares of arable land worldwide (Bermudez et al. 2012). Phytoremediation, a biological approach, uses the harvestable parts of plants to remove pollutants, represents a green and environmentalfriendly tool for cleaning metal-polluted soil and water. The use of metal-accumulating plants to clean environment is the most rapidly developing component of this environmental-friendly and cost-effective technology that has received substantial attention in recent years. The everincreasing environmental pollution due to application of sewage sludge, city refuse, and heavy metals containing fertilizers or pesticides is becoming a major problem in modern agriculture. However, there is a risk of contamination of the food chain if edible crops are used for the purpose. Now, more attention has been paid to the role of ornamental plants as a sustainable, viable and remunerative 
alternative. The non-edible crops will reduce the risk of the entry of heavy metals into the food chain (Liu et al. 2008). Many plant species have been successful in absorbing contaminants such as lead, cadmium, chromium, arsenic and various radio-nuclides from soils (Achal et al. 2012; Wojcik and Tukiendorf 2004), although some plant species are endemic to metalliferous soils and can tolerate greater than usual amounts of heavy metals or other toxic compounds (Niu et al. 2007). Thus, plant species have a dilemma with respect to balancing the uptake and maintaining concentrations of heavy metals in their tissues to cope with heavy metal stress. Nevertheless, metal-tolerant plants are either grouped as metal accumulators or metal excluder based on the bioaccumulation of metals in their roots or aerial tissues, respectively (Mani et al. 2012).

The bioavailability of heavy metals through lowering soil $\mathrm{pH}$ and adding synthetic chelates (Bennedsen et al. 2012) is an important factor for the clean-up of contaminated environment. However, these methods have some limitations due to negative effects on the chemical, physical and biological properties of the soil, or may lead to groundwater pollution through leaching. To avoid some of these constraints, the use of elemental sulphur (S) to decrease soil $\mathrm{pH}$ and increase the solubility of heavy metals in soils has been suggested (Kayser et al. 2000). However, organic inputs are always preferred on account of greener, economic and more eco-friendly view. Composting can enhance organic matter degradation and humification process, and consequently, it can reduce the toxicity of metals (Singh and Kalamdhad 2013).

In the environment, lead is known to be toxic to plants, animals and microorganisms. Since $\mathrm{Pb}^{2+}$ is not biodegradable, once soil has become contaminated, it remains for a long-term, leading to a harmful effect on biological systems (Pehlivan et al. 2009). Lead contamination poses serious human health problem, namely brain damage and retardation (Cho-Ruk et al. 2006). It inhibits various physiological and biochemical processes of fundamental significance (Kosobrukhov et al. 2004) causing visible toxicity symptoms and an ultimate reduction in vegetative and reproductive growth (Rossato et al. 2012).

Chrysanthemum indicum $\mathrm{L}$. is an abundant ornamental bioresource in India and other parts of the world. It grows in polluted areas surrounding cities. Moreover, the plant possesses key traits that make it very attractive to use in the clean-up of metal-polluted sites, e.g. ease of cultivation, rapid growth, abundant flowering and a short life cycle. Such plants require plenty of nutrients such as $\mathrm{NO}_{3}, \mathrm{PO}_{4}$, $\mathrm{Ca}, \mathrm{K}, \mathrm{Mg}, \mathrm{S}$ and micronutrients as well, which can be applied through vermicomposting having ameliorative effects on plant growth and yield as compared to inorganic fertilizers applied to soil (Singh et al. 2008), which acts as natural fertilizer for phytoremediation studies of heavy metals. It contains a high proportion of humic substances (i.e. humic acids, fulvic acids and humin) which provide numerous sites for chemical reaction. Hence, an understanding of the participation of earthworms along with application of elemental $\mathrm{S}$ in slightly alkaline soil reaction (pH $7.8 \pm 0.2)$ is basic for enhanced phytoremediation in metal-polluted soils.

With this perspective regarding problems associated with lead toxicity and its possible solution through systems biological approach for the clean-up of the contaminated soil, the present study was implemented with an aim to explore the possibility of cleaning-up the $\mathrm{Pb}$-contaminated soils through growing a non-field crop (ornamental plant), C. indicum L. during the year 2011-2013 at Sheila Dhar Institute Experimental Farm, Allahabad, India. The objectives of this study were (1) to compare the lead bioaccumulation, translocation and remediation at different concentrations of $\mathrm{Pb}$ addition with or without application of $\mathrm{S}$ and vermicompost (VC), and (2) to investigate the potential of $C$. indicum $\mathrm{L}$. for enhanced lead phytoremediation through application of S and VC.

\section{Materials and methods}

Plant material and experimental layout

The Sheila Dhar Institute experimental site, covers an area of 1 hectare, is located at Allahabad in northern India at $25^{\circ} 57^{\prime} \mathrm{N}$ latitude, $81^{\circ} 50^{\prime} \mathrm{E}$ longitude and at $120 \pm 1.4 \mathrm{~m}$ altitude. A sandy clay loam soil, derived from Indo-Gangetic alluvial soils, situated on the confluence of rivers Ganga and Yamuna alluvial deposit, was sampled for the study. The texture was sand $(>0.2 \mathrm{~mm}) 55.54 \%$, silt $(0.002-0.2 \mathrm{~mm}) 20.32 \%$ and clay $(<0.002 \mathrm{~mm}) 24.25 \%$. The detailed physicochemical properties of the investigated soil have been given in the Table 1 (Kumar and Mani 2010).

Plastic pots of a 31 capacity (each containing a mixture of $750 \mathrm{~g}$ soil and $2.25 \mathrm{~kg}$ sand) were used for the experiment. Identical-size ( $5 \mathrm{~cm}$ height) Chrysanthemum plants were transplanted into pots (single in each). The experiment was carried out in a natural light condition having daily $28{ }^{\circ} \mathrm{C}$ temperature and $12.5 \mathrm{~h}$ photoperiod.

The experiment was replicated thrice and conducted in completely randomized block design following nineteen treatments. Total 57 plastic pots (having 19 treatments replicated thrice) were installed. The treatment combinations have been mentioned under the Table 2 .

All the chemicals used in the study were of analytical reagent $(\mathrm{AR})$ grade. Lead $(\mathrm{Pb})$ was applied as lead nitrate $[\mathrm{Pb}$ $\left.\left(\mathrm{NO}_{3}\right)_{2}\right]$, and sulphur was applied as elemental sulphur. The seedlings were treated with four levels $(0,10,20$ and $50 \mathrm{mg} /$ 
Table 1 Physicochemical properties of SDI experimental soil and applied vermicompost used under the investigation

\begin{tabular}{lcc}
\hline Parameters & \multicolumn{1}{l}{ Soil } & Vermicompost \\
\hline $\mathrm{Ph}$ & $7.8 \pm 0.2$ & $6.8 \pm 0.2$ \\
$\mathrm{EC}(\mathrm{dS} / \mathrm{m})$ at $25{ }^{\circ} \mathrm{C}$ & $0.28 \pm 0.03$ & $1.06 \pm 0.08$ \\
Organic carbon $(\%)$ & $0.56 \pm 0.15$ & $13.50 \pm 0.38$ \\
$\mathrm{CEC}\left[\mathrm{C} \mathrm{mol}\left(\mathrm{p}^{+}\right) / \mathrm{kg}\right]$ & $19.6 \pm 0.6$ & $86 \pm 9.6$ \\
Total nitrogen $(\%)$ & $0.07 \pm 0.02$ & $1.33 \pm 0.22$ \\
Total phosphorus $(\%)$ & $0.038 \pm 0.01$ & $0.47 \pm 0.29$ \\
Total Pb $(\mathrm{mg} / \mathrm{kg})$ & $9.60 \pm 2.7$ & $0.16 \pm 0.03$ \\
DTPA-extractable $\mathrm{Pb}(\mathrm{mg} / \mathrm{kg})$ & $1.56 \pm 0.57$ & $0.07 \pm 0.02$ \\
\hline
\end{tabular}

\pm values indicate standard error having three replications

$E C$ electrical conductivity, $C E C$ cation exchange capacity, DTPA diethyl tri-amine penta-acetic acid, SDI Sheila Dhar Institute

Table 2 Treatment combinations used under the pot experiment at Sheila Dhar Institute experimental farm, Allahabad

\begin{tabular}{ll}
\hline Symbols & Treatment combinations \\
\hline $\mathrm{N}_{1}$ & Nitrate only $\sim 6 \mathrm{mg} / \mathrm{kg} \equiv 3.9 \mathrm{mg} / \mathrm{kg}$ ammonium nitrate \\
$\mathrm{N}_{2}$ & Nitrate only $\sim 12 \mathrm{mg} / \mathrm{kg} \equiv 7.7 \mathrm{mg} / \mathrm{kg}$ ammonium nitrate \\
$\mathrm{N}_{3}$ & $\begin{array}{c}\text { Nitrate only } \sim 30 \mathrm{mg} / \mathrm{kg} \equiv 19.3 \mathrm{mg} / \mathrm{kg} \text { ammonium } \\
\text { nitrate }\end{array}$ \\
$T_{1}$ & Control \\
$T_{2}$ & $\mathrm{~Pb} 0 \mathrm{mg} / \mathrm{kg}+\mathrm{S}($ Sulphur $) 0.8 \mathrm{~g} / \mathrm{kg}$ \\
$T_{3}$ & $\mathrm{~Pb} 0 \mathrm{mg} / \mathrm{kg}+\mathrm{VC}(\mathrm{Vermicompost}) 6 \mathrm{~g} / \mathrm{kg}$ \\
$T_{4}$ & $\mathrm{~Pb} 0 \mathrm{mg} / \mathrm{kg}+\mathrm{S} 0.8 \mathrm{~g} / \mathrm{kg}+\mathrm{VC} 6 \mathrm{~g} / \mathrm{kg}$ \\
$T_{5}$ & $\mathrm{~Pb} 10 \mathrm{mg} / \mathrm{kg} \equiv 16 \mathrm{mg} / \mathrm{kg} \mathrm{lead} \mathrm{nitrate}$ \\
$T_{6}$ & $\mathrm{~Pb} 10 \mathrm{mg} / \mathrm{kg}+\mathrm{S} 0.8 \mathrm{~g} / \mathrm{kg}$ \\
$T_{7}$ & $\mathrm{~Pb} 10 \mathrm{mg} / \mathrm{kg}+\mathrm{VC} 6 \mathrm{~g} / \mathrm{kg}$ \\
$T_{8}$ & $\mathrm{~Pb} 10 \mathrm{mg} / \mathrm{kg}+\mathrm{S} 0.8 \mathrm{~g} / \mathrm{kg}+\mathrm{VC} 6 \mathrm{~g} / \mathrm{kg}$ \\
$T_{9}$ & $\mathrm{~Pb} 20 \mathrm{mg} / \mathrm{kg} \equiv 32 \mathrm{mg} / \mathrm{kg} \mathrm{lead} \mathrm{nitrate}$ \\
$T_{10}$ & $\mathrm{~Pb} 20 \mathrm{mg} / \mathrm{kg}+\mathrm{S} 0.8 \mathrm{~g} / \mathrm{kg}$ \\
$T_{11}$ & $\mathrm{~Pb} 20 \mathrm{mg} / \mathrm{kg}+\mathrm{VC} 6 \mathrm{~g} / \mathrm{kg}$ \\
$T_{12}$ & $\mathrm{~Pb} 20 \mathrm{mg} / \mathrm{kg}+0.8 \mathrm{~g} / \mathrm{kg} \mathrm{S}+6 \mathrm{~g} / \mathrm{kg} \mathrm{VC}$ \\
$T_{13}$ & $\mathrm{~Pb} 50 \mathrm{mg} / \mathrm{kg} \equiv 80 \mathrm{mg} / \mathrm{kg}$ lead nitrate \\
$T_{14}$ & $\mathrm{~Pb} 50 \mathrm{mg} / \mathrm{kg}+0.8 \mathrm{~g} / \mathrm{kg} \mathrm{S}$ \\
$T_{15}$ & $\mathrm{~Pb} 50 \mathrm{mg} / \mathrm{kg}+6 \mathrm{~g} / \mathrm{kg} \mathrm{VC}$ \\
$T_{16}$ & $\mathrm{~Pb} 50 \mathrm{mg} / \mathrm{kg}+0.8 \mathrm{~g} / \mathrm{kg} \mathrm{S}+6 \mathrm{~g} / \mathrm{kg} \mathrm{VC}$ \\
\hline
\end{tabular}

$\mathrm{kg}$ ) of $\mathrm{Pb}$, and after $24 \mathrm{~h}$ of the treatment, they were transplanted under nineteen treatments. Since nitrate is an important plant nutrient, nitrate-only control pots were also run. In order to normalize three added dosage of nitrate with increasing concentration of $\mathrm{Pb}(10,20$ and $50 \mathrm{mg} / \mathrm{kg})$, three levels $(5.985,11.969$ and $29.923 \mathrm{mg} / \mathrm{kg}$ ) of nitrate were applied through ammonium nitrate, respectively. Under different levels of applied $\mathrm{Pb}$ pots, the percentage increases or decreases in parameters were determined over their respective nitrate-only control pots. In order to allow the stabilization of adsorption-desorption reactions, soils were incubated with VC for one month at field water capacity (80\%) before planting Chrysanthemum. Elemental sulphur was applied in the pots before the transplantation of the seedlings. The quality of $\mathrm{VC}$ is given under Table 1 . Soil moisture was maintained by irrigating the crops at intervals of 5-6 days. C. indicum L. was harvested at 60 days after transplanting for the aforesaid analyses.

Soil sampling

The larger fields were divided into suitable and uniform parts, and each of these uniform parts was considered a separate sampling unit. In each sampling unit, soil samples were drawn from several spots in a zigzag pattern, leaving about 2-m area along the field margins. Silt and clay were separated by pipette method and fine sand by decantation (Chopra and Kanwar 1999).

Extraction for lead $(\mathrm{Pb})$ content in soil

For total $\mathrm{Pb}$ content, one gram of soil was mixed in $5 \mathrm{ml}$ of $\mathrm{HNO}_{3}(16 \mathrm{M}, 71 \%)$ and $5 \mathrm{ml}$ of $\mathrm{HClO}_{4}(11 \mathrm{M}, 71 \%)$. The composite was heated up to dryness. The hot distilled water was added. The contents were filtrated, and volume was made up to $50 \mathrm{ml}$. The clean filtrate was used for the estimation of heavy metals $(\mathrm{Pb})$ by atomic absorption spectrophotometer (AAS) (AAnalyst600, PerkinElmer Inc., MA, USA). For available $\mathrm{Pb}, 5$ gram of soil was mixed with $20 \mathrm{ml}$ DTPA solution (Di-ethyl-tri-amine-pentaacetic acid (DTPA) solution [1.97 g (0.05 M) DTPA powder, $13.3 \mathrm{ml}(0.1 \mathrm{M})$ Tri-ethanol amine and $1.47 \mathrm{~g}$ (0.01 M) $\mathrm{CaCl}_{2}$ were dissolved in distilled water (Lindsay and Norvell 1978) and were made up to 11 after adjusting the $\mathrm{pH}$ to 7.3] was added \} and the contents were shaken for $2 \mathrm{~h}$ and then filtered through Whatman filter paper No. 42 . The clean filtrate was used for the estimation of $\mathrm{Pb}$ by the aforesaid spectrophotometer.

Soil $\mathrm{pH}$

Soil $\mathrm{pH}$ was measured with 1:2.5 soil-water ratio using Elico digital pH meter (Model LI 127, Elico Ltd., Hyderabad, India) at the Laboratory of Sheila Dhar Institute of Soil Science, University of Allahabad, Allahabad-211002, Uttar Pradesh, India. Double distilled water was used for the preparation of all solutions.

\section{Organic carbon}

One gram soil was digested with $10 \mathrm{ml}$ of $1 \mathrm{~N}$ potassium dichromate $\left(\mathrm{K}_{2} \mathrm{Cr}_{2} \mathrm{O}_{7}\right)$ solution and $20 \mathrm{ml}$ of concentrated sulphuric acid (18 M, $96 \%)$. The solution was shaken well for 2 min and kept for half an hour and then diluted with 
$200 \mathrm{ml}$ of distilled water. Then, $10 \mathrm{ml}$ of ortho-phosphoric acid $(15 \mathrm{M}, 85 \%)$ and $1 \mathrm{ml}$ of diphenylamine indicator were added in solution. The solution became deep violet in colour, and further it was titrated against N/2 ferrous ammonium sulphate solution, till the violet colour changed to purple and finally to green (Chopra and Kanwar 1999).

\section{Cation exchange capacity (CEC)}

CEC was determined by using neutral $1 \mathrm{~N}$ ammonium acetate solution. A known weight of soil (5 g) was shaken with $25 \mathrm{ml}$ of the acetate solution for $5 \mathrm{~min}$ and filtered through Whatman filter paper No. 42 (Chopra and Kanwar 1999).

\section{Total nitrogen}

One gram soil was digested with $10 \mathrm{ml}$ of digestion mixture containing sulphuric acid and selenium dioxide. Salicylic acid was also added to include the nitrates and nitrites. Digestion was carried out till the soil colour changed to white. The $N$ in the digest was estimated by using micro-Kjeldahl method, Glass Agencies, Ambala, India (Chopra and Kanwar 1999).

\section{Total phosphorus}

Two gram soil was taken with $4 \mathrm{ml} \mathrm{HClO}_{4}(11 \mathrm{M}, 71 \%)$ in a $50-\mathrm{ml}$ beaker covered with watch glass and put on a hot plate, and digestion was carried out till the soil colour changes to white. Ten $\mathrm{ml} \mathrm{HNO}_{3}(16 \mathrm{M}, 71 \%)$ was added to the filtrate solution. Ammonia was added to saturate the solution. Then $30 \mathrm{ml}$ standard ammonium molybdate solution was added in the solution to extract the total phosphorus content from soil (Kumar and Mani 2010).

\section{Processing plant samples}

Plants were harvested after 60 days having higher phytochemicals at their maturity stage as suggested by Mani et al. (2012). Plant samples were carefully rinsed with tap water followed by $0.2 \%$ detergent solution, $0.1 \mathrm{~N} \mathrm{HCl}$, deionized water and double distilled water. Samples were then soaked with tissue paper, air-dried for 2-3 days in a dust- and contaminant-free environment, placed in clean paper envelopes, dried in a hot-air oven at a temperature of $45^{\circ} \mathrm{C}$, and ground to a fine powder. Plant biomass dry weights were recorded. Flowers, shoots and roots were separated and analysed.

Determination of lead in plant extract

One gram of ground plant material was digested with $15 \mathrm{ml}$ of tri-acid mixture containing conc. $\mathrm{HNO}_{3}(16 \mathrm{M}$,
$71 \%), \mathrm{H}_{2} \mathrm{SO}_{4}(18 \mathrm{M}, 96 \%)$ and $\mathrm{HClO}_{4}(11 \mathrm{M}, 71 \%)$ in $5: 1: 2)$. The composite was heated on hot plate at low heat $\left(60{ }^{\circ} \mathrm{C}\right)$ for $30 \mathrm{~min}$, and the volume was reduced to about $5 \mathrm{ml}$ until a transparent solution was obtained. After cooling, $20 \mathrm{ml}$ distilled water was added and the content was filtered through Whatman filter paper No. 42 (Kumar and Mani 2010). Total $\mathrm{Pb}$ was determined by the aforesaid Spectrophotometer.

\section{Determination of photosynthetic pigments by HPLC}

The upper second fully expanded leaves were sampled for analysis of photosynthetic pigments, at 60th day. The photosynthetic pigments (chlorophyll-a, chlorophyll-b and carotenoid) were extracted using the method of Barba et al. (2006) with minor modifications. In brief, $2 \mathrm{~g}$ sample was ground in $10 \mathrm{ml}$ of $100 \%$ methanol, centrifuged at $5,000 \mathrm{rpm}$ for $20 \mathrm{~min}$ to separate the supernatant, and these operations were repeated until the sample became colourless. The extract was filtered through Whatman No. 1 filter paper and then through $0.45-\mu \mathrm{m}$ membrane filter. About $20 \mu \mathrm{l}$ sample was injected for HPLC analysis. Analysis was performed using reversed phase chromatography (RPHPLC) using DIONEX Ultimate 3,000 series, comprising a solvent rack (SRD-3200), a pump (HPG-3200SD), a column oven (TCC-3000SD), and a diode array detector (variable wavelength detectors VWD-3100 and VWD3400). The mobile phase consisted of methanol and acetonitrile in 9:1 ratio at a flow rate of $1.0 \mathrm{ml}$ per min. The column temperature was kept $22{ }^{\circ} \mathrm{C}$. The wavelengths used to indicate the pigments were $430 \mathrm{~nm}$ for chlorophyll- $a$, and $450 \mathrm{~nm}$ for chlorophyll- $b$ and carotenoid.

Bioaccumulation factor, translocation factor and remediation ratio

Bioaccumulation factor (BF), defined as the ratio of chemical concentration in a plant (root and shoot tissues) to soil, is used to measure the effectiveness of a plant in concentrating pollutant into aerial part (Fayiga et al. 2004), and translocation factor (TF), the quotient of contaminant concentration in shoots to roots, which is used to measure the effectiveness of a plant in transferring a chemical from roots to shoots (Sun et al. 2011). Bioaccumulation factor (BFs) is calculated according to the following formula.

$\mathrm{BFs}=\frac{M_{\text {shoot }}}{M_{\text {soil }}}$

where $M_{\text {shoot }}$ is the metal content ( $\mathrm{mg} / \mathrm{kg}$ dry wt) in shoots, $M_{\text {soil }}$ is the total metal content $(\mathrm{mg} / \mathrm{kg})$ in the soil. $M_{\text {soil }}$ was calculated by adding total metal content in soil naturally with applied metal content in soil. Translocation factor (TFs) is calculated according to the following formula: 
$\mathrm{TFs}=\frac{M_{\text {shoot }}}{M_{\text {root }}}$

where $M_{\text {root }}$ is the metal concentration in roots of the plants $(\mathrm{mg} / \mathrm{kg})$.

The remediation ratio (RR) or remediation efficiency (ER) is defined as the ratio of an element accumulation in shoots to that in soil, which is calculated as follows:

$\operatorname{ER}(\%)=\frac{M_{\text {shoot }} \times W_{\text {shoot }}}{M_{\text {soil }} \times W_{\text {soil }}} \times 100 \%$

where $W_{\text {shoot }}$ is the plant dry above-ground biomass (g) and $W_{\text {soil }}$ is the amount of soil in the pot (g). The RR values reflect the amount of a metal remediation by a plant from soil.

Data were analysed by factorial analysis of variation (ANOVA) using various treatments as independent factors with the help of the sum of square (SS) and degree of freedom (DF). The standard error (SE) is given by $\mathrm{SE}=\sqrt{\frac{2 V_{\mathrm{E}}}{n}}$, where $V_{\mathrm{E}}$ is the variance due to the error and $n$ is the number of replications. All treatments were replicated thrice in the experiment. GraphPad Prism (version 5.04, GraphPad Software, USA) software was used for drawing figures.

\section{Results and discussion}

Effect of lead, elemental sulphur and vermicompost on root growth

The data presented in the Fig. 1 indicated that the combined application of $10 \mathrm{mg} / \mathrm{kg} \mathrm{Pb}$ along with $0.8 \mathrm{~g} / \mathrm{kg} \mathrm{S}$ and $6 \mathrm{~g} / \mathrm{kg} \mathrm{VC}$ boosted root length up to the maximum of $14.78 \mathrm{~cm}$, which was observed $9.89 \%$ higher over the respective control $\left(\mathrm{N}_{1}\right)$. Application of $\mathrm{Pb}$ at $10 \mathrm{mg} / \mathrm{kg}$ along with $\mathrm{S}$ or $\mathrm{VC}$ or both caused root elongation by 7.8-9.9\% over the respective control $\left(\mathrm{N}_{1}\right)$. However, the composite application of S and VC elongated the roots by 3.05-3.8 \% over their respective non-amended pots. The individual application of $50 \mathrm{mg} / \mathrm{kg} \mathrm{Pb}$ altered root growth which was observed minimum $(9.26 \mathrm{~cm})$ leading to $31.15 \%$ reduction over the respective control $\left(\mathrm{N}_{3}\right)$. The study clearly indicates that lead has inhibitory effect on root length. Reduction in root growth is possible due to restriction in cell division and cell elongation (Malkowski et al. 2002). Root toxicity symptom included reduced number of roots hair, browning and stunted growth as compared to the control treatment (without $\mathrm{Pb}$ ), where plant roots were healthy and normal. Boonyapookana et al. (2005) also observed similar results using $H$. annиus L. in $\mathrm{Pb}$-contaminated soil. The statistical analysis reveals that different amendments under treatments $T_{1}-T_{16}$ non-

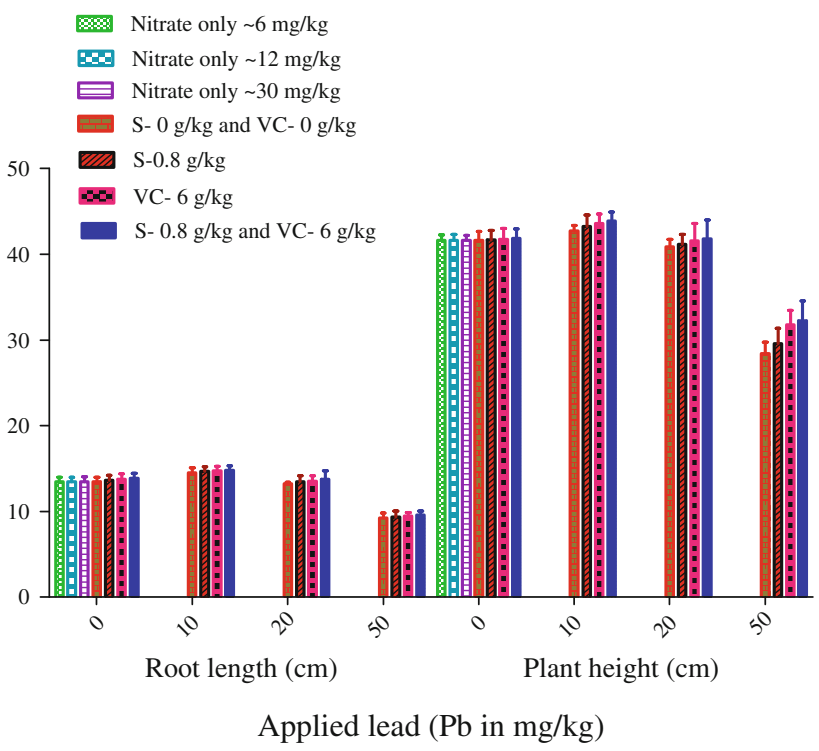

Fig. 1 Effect of different levels of lead, elemental sulphur and vermicompost on elongation of root and shoot of $C$. indicum $\mathrm{L}$.

significantly $(P=0.8432)$ enhanced the root elongation while different levels of $\mathrm{Pb}$ significantly $(P<0.0001)$ diminished the root length of the plant. However, the differences among control $\left(T_{1}\right)$ and nitrate-only controls $\left(\mathrm{N}_{1}\right.$, $\left.\mathrm{N}_{2}, \mathrm{~N}_{3}\right)$ were observed non-significant $(F=0.0054)$. Comparing the root length obtained under treatments $T_{12}$ $T_{16}$, the trend was observed in the order of $T_{12}>T_{16}>T_{15}>T_{14}>T_{13}$. The present study indicated that application of $\mathrm{Pb}$ up to $20 \mathrm{mg} / \mathrm{kg}$ did not able to retard the growth of roots significantly; however, $\mathrm{Pb}$ at $50 \mathrm{mg} / \mathrm{kg}$, either individually or in combination with sulphur and vermicompost, drastically retarded the growth. It may be due to increase in antioxidant activities of plants at lower level of lead (Kosobrukhov et al. 2004; Kaur et al. 2012), which has been discussed further under different subheadings.

Effect of lead, elemental sulphur and vermicompost on shoot growth

The data presented in the Fig. 1 indicated that individual application of $50 \mathrm{mg} / \mathrm{kg} \mathrm{Pb}$ altered shoot growth to produce minimum height $(28.45 \mathrm{~cm})$ which was recorded $31.71 \%$ decrease over the respective control $\left(\mathrm{N}_{3}\right)$; however, application of $20 \mathrm{mg} / \mathrm{kg} \mathrm{Pb}$ did not alter shoot height $(40.84 \mathrm{~cm})$ of the plants. The application of $10 \mathrm{mg} / \mathrm{kg} \mathrm{Pb}$ along with $\mathrm{S}$ and $\mathrm{VC}$ produced maximum plant height $(43.85 \mathrm{~cm})$. Chand et al. (2012) also observed similar findings that lower level of $\mathrm{Pb}$ along with $\mathrm{VC}$ increased plant height up to the maximum. Soil amendments through $\mathrm{S}$ or VC or both caused shoot elongation by 3.84-5.28\% over the respective control $\left(\mathrm{N}_{1}\right)$ in the $\mathrm{Pb}$-contaminated 
pots at $10 \mathrm{mg} / \mathrm{kg}$. On the other hand, individual application of $\mathrm{Pb}$ at $50 \mathrm{mg} / \mathrm{kg}$ reduced the elongation of shoot by $31.71 \%$ over the respective control $\left(\mathrm{N}_{3}\right)$. The statistical analysis reveals that different amendments or column factors under treatments $T_{1}-T_{16}$ non-significantly $(P=0.4558)$ enhanced the shoot elongation while different levels of $\mathrm{Pb}$ or row factors significantly $(P<0.0001)$ diminished the shoot length of the plant. However, the differences among control $\left(T_{1}\right)$ and nitrate-only controls $\left(\mathrm{N}_{1}, \mathrm{~N}_{2}, \mathrm{~N}_{3}\right)$ were observed non-significant $(F=0.306)$. Comparing the shoot length obtained under treatments $T_{12}-$ $T_{16}$, the trend was observed in the order of $T_{12}>T_{16}>T_{15}>T_{14}>T_{13}$. The study clearly indicated that application of $\mathrm{Pb}$ up to $20 \mathrm{mg} / \mathrm{kg}$ did not able to retard plant height significantly; however, $\mathrm{Pb}$ at $50 \mathrm{mg} / \mathrm{kg}$, either individually or in combination with sulphur and vermicompost, drastically retarded the growth. The composite application of $\mathrm{S}$ and $\mathrm{VC}$ caused shoot elongation by $0.5-13.3 \%$ over their respective non-amended pots. The present study reveals that the ameliorative response of $\mathrm{S}$ and $\mathrm{VC}$ was observed higher in moderately to higher $\mathrm{Pb}$ contaminated $(\geq 20 \mathrm{mg} / \mathrm{kg}$ ) pots.

Effect of lead, elemental sulphur and vermicompost on root and shoot dry biomass of $C$. indicum $\mathrm{L}$.

The data presented in the Fig. 2 indicated almost similar trend that combined application of $10 \mathrm{mg} / \mathrm{kg} \mathrm{Pb}$ along with $\mathrm{S}$ and VC produced maximum root and shoot dry biomass up to the extent of 1.26 and $4.22 \mathrm{~g} /$ pot, respectively, which were recorded 18.5 and $10.47 \%$ increase over the respective control $\left(\mathrm{N}_{1}\right)$. Application of $\mathrm{VC}$ at different levels of $\mathrm{Pb}$ $(10,20$ and $50 \mathrm{mg} / \mathrm{kg})$ treated pots produced root dry biomass of 1.21, 0.96 and $0.81 \mathrm{~g} /$ pot, resulted in 7.08, 11.63 and $12.5 \%$ increase over their respective non-amended pots. Similarly application of $\mathrm{VC}$ at the aforesaid levels of $\mathrm{Pb}$-treated pots produced shoot dry biomass of $4.16,3.86$ and $2.38 \mathrm{~g} / \mathrm{pot}$, resulted in 5.32, 3.76 and $5.78 \%$ increase over their non-amended pots. The statistical analysis reveals that different amendments under treatments $T_{1}-T_{16}$ significantly $(P=0.0001)$ enhanced root dry biomass and significantly $(P=0.0032)$ enhanced shoot dry biomass of the plant. However, the differences among control $\left(T_{1}\right)$ and nitrate-only controls $\left(\mathrm{N}_{1}, \mathrm{~N}_{2}, \mathrm{~N}_{3}\right)$ were observed non-significant on influencing root biomass $(F=0.0356)$ and shoot biomass $(F=0.0046)$ of the plant. While different levels of $\mathrm{Pb}$ significantly $(P<0.0001)$ diminished both root and shoot dry biomass of the plant, the present study clearly showed ameliorative role of $\mathrm{VC}$ on the biomass yield (Chand et al. 2012; Pande et al. 2007). The combined application of $10 \mathrm{mg} / \mathrm{kg} \mathrm{Pb}$ along with $\mathrm{S}$ also enhanced the root and shoot dry biomass production which were observed 1.17 and $4.12 \mathrm{~g} /$ pot, resulted in 9.72 and $7.85 \%$ increase

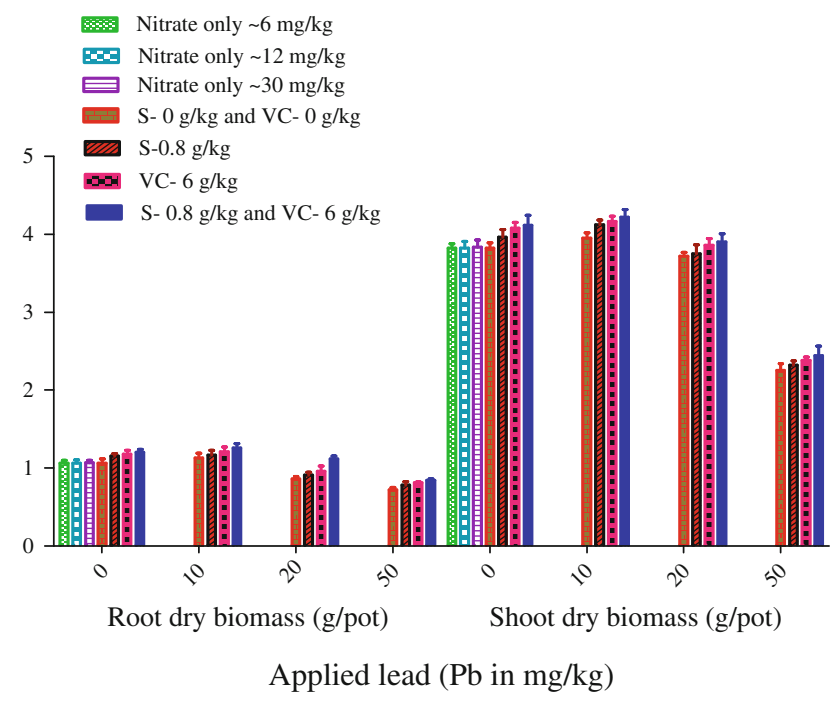

Fig. 2 Effect of different levels of lead, elemental sulphur and vermicompost on dry biomass of root and shoot in C. indicum $\mathrm{L}$.

over the respective control $\left(\mathrm{N}_{1}\right)$, respectively, indicating ameliorative role of sulphur addition in pots (Dede et al. 2012). Comparing the biomass of root and shoot under treatments $T_{12}-T_{16}$, almost similar trend was observed in the order of $T_{12}>T_{16}>T_{15}>T_{14}>T_{13}$. The application of $\mathrm{Pb}$ at $50 \mathrm{mg} / \mathrm{kg}$ registered the minimum dry biomass of root and shoot up to 0.72 and $2.25 \mathrm{~g} /$ pot showing maximum retardation in growth to the extent of 32.71 and $41.25 \%$, respectively, over the control $\left(\mathrm{N}_{3}\right)$ due to the presence of excess $\mathrm{Pb}$ in the root environment. The entry of $\mathrm{Pb}$ into the plants must be monitored to minimize the possible risk of the metals toxicity into the plants. However, the contaminated plants must be disposed off safely for the phytoremediation purpose.

Bioaccumulation of lead in the root, shoot and flower of $C$. indicum $\mathrm{L}$.

The data graphically presented in Fig. 3 indicated that lead addition $\quad(0-50 \mathrm{mg} / \mathrm{kg}) \quad$ significantly $\quad(P<0.0001)$ enhanced the concentration of $\mathrm{Pb}$ (in $\mathrm{mg} / \mathrm{kg}$ ) in root, shoot and flower of $C$. indicum $\mathrm{L}$., which were observed $0.67-38.46,0.34-19.87$ and $0.25-7.62$, respectively. Roots were observed highly contaminated with $\mathrm{Pb}$ as compared to shoots and flowers. Lead content in plant tissues was proportionate to the lead levels in the soils. The translocation of lead ions to the aerial tissues occurs because with plant development, root endoderm may become weak barrier. For this reason, metals easily penetrate xylem and then the above-ground parts of plants. Consequently, plants accumulate higher levels of metal in the roots with slow translocation to the shoots. Similar pattern of metal accumulation has been reported to accumulate rapidly and 


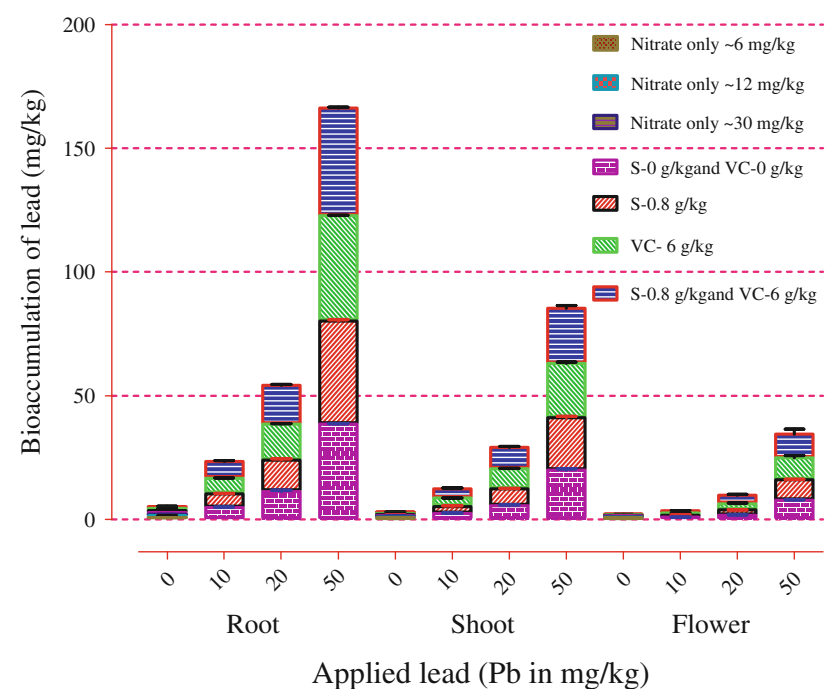

Fig. 3 Bioaccumulation of lead in root, shoot and flower of $C$. indicum $\mathrm{L}$.

preferentially in the roots with little being translocated to the other parts of the plant (Boonyapookana et al. 2005).

Comparing the bioaccumulation of $\mathrm{Pb}$ (in root, shoot and flower) under treatments $T_{12}-T_{16}$, the trend was observed in the order of $T_{16}>T_{15}>T_{14}>T_{13}>T_{12}$. The combined application of $50 \mathrm{mg} / \mathrm{kg} \mathrm{Pb}$ along with $\mathrm{S}$ and $\mathrm{VC}$ $\left(T_{16}\right)$ registered the maximum concentration $(43.58,22.45$ and $9.62 \mathrm{mg} / \mathrm{kg}$, respectively) of $\mathrm{Pb}$ in root, shoot and flower of $C$. indicum $\mathrm{L}$. The study revealed that $\mathrm{S}$ would be an effective amendment for phytoremediation of $\mathrm{Pb}$ from $\mathrm{Pb}$-contaminated soil (Dede et al. 2012) by growing $C$. indicum $\mathrm{L}$. The statistical analysis reveals that different amendments (column factors) under treatments $T_{1}-T_{16}$, levels of $\mathrm{Pb}$ (row factors) and their interaction were observed highly significant $(P<0.0001)$ on affecting the $\mathrm{Pb}$ accumulation in different tissues of the plant. However, the differences among control $\left(T_{1}\right)$ and nitrate-only controls $\left(\mathrm{N}_{1}, \mathrm{~N}_{2}, \mathrm{~N}_{3}\right)$ were observed non-significant on influencing bioaccumulation in root $(F=0.02)$, shoot $(F<0.04)$ and flower $(F<0.07)$ of the plant. The results indicate that maximum potential of plants can be utilized in the combinatorial treatments to enhance $\mathrm{Pb}$ phytoremediation from the $\mathrm{Pb}$-contaminated pots. Higher bioaccumulation of $\mathrm{Pb}$ in the combined application of $\mathrm{Pb}$ along with $\mathrm{S}$ and $\mathrm{VC}$ might be ascribed due to lowering of $\mathrm{pH}$ as a result of production of sulphuric acid and organic acids. Lowering of $\mathrm{pH}$ promoted the availability of $\mathrm{Pb}$ in the investigated soil (Antoniadis et al. 2008).

The graphical illustration (Fig. 3) indicated that magnitude of accumulation of lead was higher in root tissues as compared to shoot and flower tissues (Patra et al. 2004). Addition of $\mathrm{VC}$ was presumed to mobilize the $\mathrm{Pb}$ in the rhizosphere by producing organic acids having lower molecular weight, responsible for formation of organic ligands. Accumulation of $\mathrm{Pb}$ in root might be attributed to binding of this metal to exchange sites mainly in the form of lead carbonates with the mechanisms occurring in the cell walls (Jarvis and Leung 2002). Vermicompost favours phytoextraction of $\mathrm{Pb}$ as a high source of organic matter through production of phytochelatin. Organic matter in soil effectively increases the activity of metals in soil and improves metal mobility and distribution in soil. The application of vermicompost in soil promoted the mobility of lead through the formation of soluble metal organic complexes (Yang et al. 2005). In addition, exudation of organic compounds by plant roots, such as organic acids, influences ion solubility and uptake of heavy metals through their effects on microbial activity, rhizosphere physical properties and root growth dynamics (Yang et al. 2005).

The present study indicated enhanced metal accumulation in all parts of plants (roots, shoots and flowers) especially when lead was applied in combination with $S$ and VC. Thus, phytoaccumulation potential of $C$. indicum L. was verified, and its potential was improved with the application of elemental S and VC. It is also worth mentioning that there is drastic decrease in growth of plants (roots, shoots as well as dry biomass) when $\mathrm{Pb}$ was applied at $20 \mathrm{mg} / \mathrm{kg}$ or more. The entry of $\mathrm{Pb}$ into the plants must be monitored to minimize the possible risk of the metals toxicity into the plants. However, the contaminated plants must be disposed off safely for the phytoremediation purpose.

Effect of lead, elemental sulphur and vermicompost on photosynthetic pigments of $C$. indicum $\mathrm{L}$.

The data graphically presented in Fig. 4a-c indicated that varying levels of lead addition significantly $(P<0.0001)$ decreased the photosynthetic pigments in the leaves of $C$. indicum $\mathrm{L}$. The successive addition of $\mathrm{Pb}$ from 0 to $50 \mathrm{mg} /$ $\mathrm{kg}$ diminished the chlorophyll-a content in leaves from 0.422 to $0.216 \mathrm{mg} / \mathrm{g}$ fresh weight (FW). Elloumi et al. (2007) corroborated almost similar results. However, application of $\mathrm{Pb}$ at $10 \mathrm{mg} / \mathrm{kg}$ increased the chlorophyll-b and total carotenoid content as compared to the control pots. The application of $\mathrm{Pb}$ at $50 \mathrm{mg} / \mathrm{kg}$ registered the minimum chlorophyll-b and total carotenoid content in leaves to the extent of 0.102 and $0.148 \mathrm{mg} / \mathrm{g} \mathrm{FW}$, respectively.

The combined application of $\mathrm{Pb}$ at $10 \mathrm{mg} / \mathrm{kg}$ along with $\mathrm{S}$ and VC registered the maximum chlorophyll-b and total carotenoid contents in leaves to the extent of 0.192 and $0.249 \mathrm{mg} / \mathrm{g} \mathrm{FW}$, respectively. However, the combinatorial application of $\mathrm{S}$ and $\mathrm{VC}$ registered produced the maximum chlorophyll-a content in leaves to the extent of $0.438 \mathrm{mg} / \mathrm{g}$ FW. 

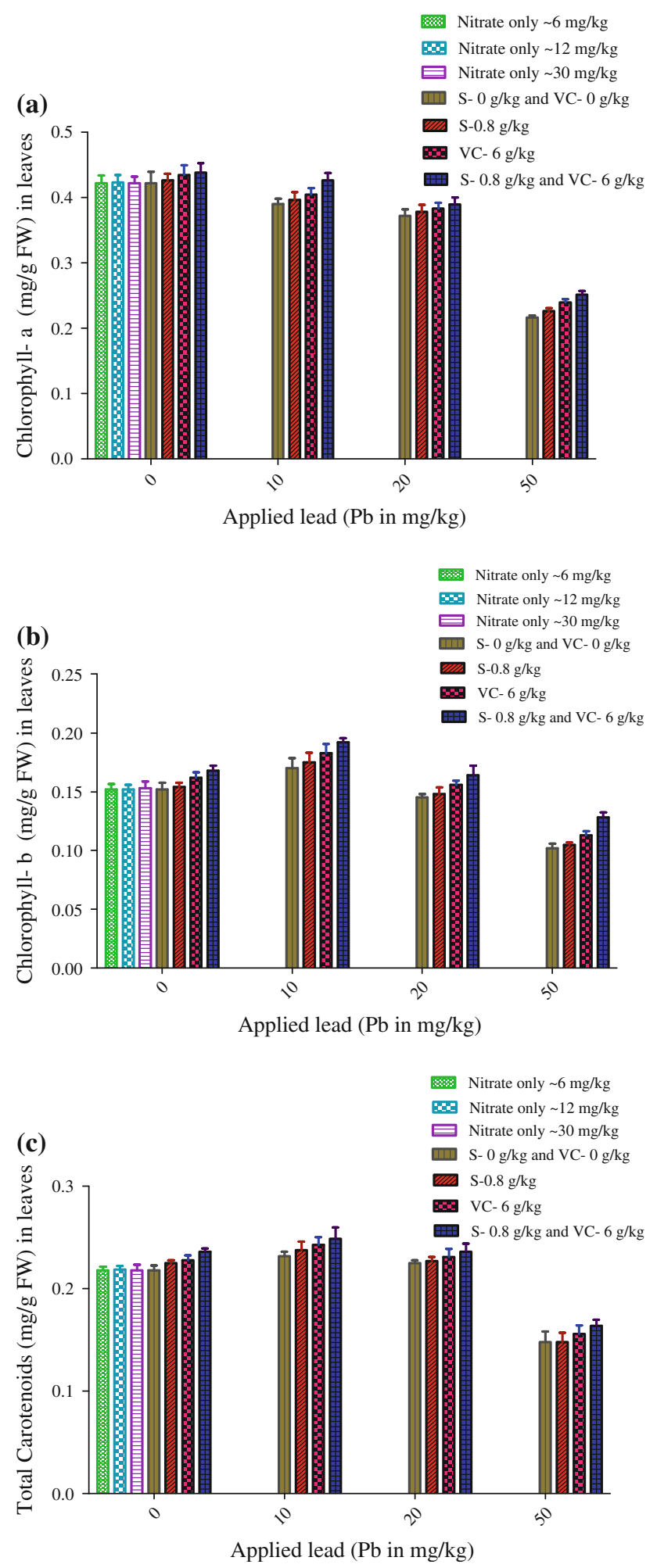

Fig. 4 Effect of different treatments on a chlorophyll-a, b chlorophyll-b and $\mathbf{c}$ total carotenoid content $(\mathrm{mg} / \mathrm{g} \mathrm{FW})$ in leaves of $C$. indicum $\mathrm{L}$.

The application of S increased chlorophyll-a, chlorophyll-b and total carotenoid contents in leaves to the extent of $0.426,0.154$ and $0.225 \mathrm{mg} / \mathrm{g} \mathrm{FW}$, respectively, as compared to the control pots. On the other hand, under S deficiency, shortage of the sulphur-containing amino acid methionine and cysteine not only leads to inhibition of protein synthesis but also decreases the chlorophyll content in the leaves.

The application of VC promoted the chlorophyll-a, chlorophyll-b and total carotenoid contents in leaves up to the extent of $0.434,0.162$ and $0.228 \mathrm{mg} / \mathrm{g} \mathrm{FW}$, which were recorded 2.84, 6.58 and $4.59 \%$ higher as compared to the control pots, respectively. Almost similar result was reported by Mathivanan et al. (2012) using groundnut plants.

Application of $\mathrm{S}$ and $\mathrm{VC}$ boosted the photosynthetic pigments in $C$. indicum $\mathrm{L}$. which led to enhanced plant photosynthetic activities to counter the hazardous effect of $\mathrm{Pb}$-contaminated pots. Application of either $\mathrm{S}$ or $\mathrm{VC}$ or both enhanced the chlorophyll-a and chlorophyll-b contents by 0.95 to $10.53 \%$ over the control in Pb-uncontaminated soil. However, this increment was observed 1.54-12.94, 1.61-13.1 and 2.94-25.49 \% in Pb-contaminated soils at 10,20 and $50 \mathrm{mg} / \mathrm{kg}$, respectively. The statistical analysis showed that different amendments under treatments $T_{1}-T_{16}$ significantly boosted the content of chlorophyll-a $(P=0.0093)$, chlorophyll-b $(P<0.0001)$ and total carotenoids $(P=0.0206)$ under the experiment. However, the differences among control $\left(T_{1}\right)$ and nitrateonly controls $\left(\mathrm{N}_{1}, \mathrm{~N}_{2}, \mathrm{~N}_{3}\right)$ were observed non-significant on influencing chlorophyll-a $(F<0.007)$, chlorophyll-b $(F<0.034)$ and carotenoid $(F<0.045)$ contents of the plant. Different levels of $\mathrm{Pb}$ significantly $(P<0.0001)$ reduced the photosynthetic pigments in the leaves of the plant as compared to the control pots. Comparing the content of photosynthetic pigments under treatments $T_{12}$ $T_{16}$, the trend was observed in the order of $T_{12}>T_{16}>T_{15}>T_{14}>T_{13}$. The study clearly indicated that application of $\mathrm{Pb}$ up to $20 \mathrm{mg} / \mathrm{kg}$ did not able to retard photosynthetic pigments significantly; however, $\mathrm{Pb}$ at $50 \mathrm{mg} / \mathrm{kg}$, either individually or in combination with sulphur and vermicompost, retarded the content of the photosynthetic pigments drastically. However, the plants having amended treatments showed lower decrease in the pigment contents. The reduction in photosynthetic pigments could be attributed to the degradation of chloroplast at higher levels of $\mathrm{Pb}$ (Kaur et al. 2012). In fact, $\mathrm{Pb}$ has a low redox potential and therefore it cannot participate in biological redox reactions, but there exists some evidence that it could perform oxidative-related disturbances, including lipid peroxidation (Sandalio et al. 2001). Moreover, excessive amount of lead has also been reported to cause irreversible degradation of pigment molecules (Madhu et al. 2008). The present study indicates that photosynthetic pigments play an important role in the physiology of plants especially for protection mechanism against $\mathrm{Pb}$ stress condition. 
Effect of lead, elemental sulphur and vermicompost on pre-/post-harvest total/available $\mathrm{Pb}$ in soil and $\mathrm{Pb}$ uptake by plant

The data presented in the Table 3 indicated that the combined application of $20 \mathrm{mg} / \mathrm{kg} \mathrm{Pb}$ along with $0.8 \mathrm{~g} / \mathrm{kg} \mathrm{S}$ and $6 \mathrm{~g} / \mathrm{kg}$ VC caused maximum reduction in available $\mathrm{Pb}$ and total $\mathrm{Pb}$ in the post-harvest soils which were calculated 33.94 and $6.8 \%$ over the pre-harvest soils, respectively. However, either control or nitrate-only control plots showed minimum reduction in available $\mathrm{Pb}$ and total $\mathrm{Pb}$ to the extent of 18.59 and $2.08 \%$, respectively. All nonamended plots showed lower reduction in available $\mathrm{Pb}$ and total $\mathrm{Pb}$ from pre-harvest to post-harvest analysis to the extent of $<28$ and $<4 \%$, respectively. The study clearly indicated that reduction in available $\mathrm{Pb}$ was observed higher in magnitude than that of total $\mathrm{Pb}$ (Table 3). In the present study, the combinatorial treatments $\left(T_{4}, T_{8}, T_{12}\right.$ and $T_{16}$ ) caused $25.16-33.94 \%$ reduction in available $\mathrm{Pb}$ from pre-harvest to post-harvest experiment. This might be possible due to involvement of vermicompost acting as a supporting media for growth of bio-inoculants to colonize bacteria especially plant growth promoting rhizobacteria like Azotobacter, Azospirillum, Bacillus and Pseudomonas species (Singh et al. 2011).
Successive dosage of applied $\mathrm{Pb} \quad(0-50 \mathrm{mg} / \mathrm{kg})$ increased the $\mathrm{Pb}$ uptake by plants from the minimum $(0.41 \mathrm{mg} / \mathrm{kg}$ dry biomass) in control plot to the maximum (27.86 $\mathrm{mg} / \mathrm{kg}$ dry biomass) in combinatorial treatment $\left(T_{16}\right)$. Although the study indicated significant removal of available $\mathrm{Pb}$ from soil, $\mathrm{Pb}$ uptake remained moderate under the experiment. This may be possibly due to high adsorption of $\mathrm{Pb}$ on soil-colloidal complexes (not studied in the present work). Comparing the uptake of $\mathrm{Pb}$ under treatments $T_{12}-T_{16}$, the trend was observed in the order of $T_{16}>T_{15}>T_{14}>T_{13}>T_{12}$. The study clearly indicated successive increase in $\mathrm{Pb}$ uptake as per increase in the application of $\mathrm{Pb}$ from 0 to $50 \mathrm{mg} / \mathrm{kg}$. Also, the amended pots with sulphur and vermicompost resulted in higher uptake of $\mathrm{Pb}$ than that of non-amended pots.

Although $C$. indicum L. under combinatorial treatments showed moderate or intermediate ranking for $\mathrm{Pb}$ uptake among several plants species reported earlier, the tested ornamental plant species along with vermicomposting technology would have more relevance for $\mathrm{Pb}$ harvest from a metal contaminated soils in terms of eco-friendly and sustainable approach, lower risk of contamination of food crops, and it is easy to robust application on a large-scale contaminated fields by the common mass/people. Due to its simplicity and flexibility, vermiculture may be carried out for

Table 3 Effect of different levels of lead, elemental sulphur and vermicompost on pre-/post-harvest total $\mathrm{Pb}$ and available $\mathrm{Pb}$ in soil, and $\mathrm{Pb}$ uptake $(\mathrm{mg} / \mathrm{kg}$ dry biomass) by C. indicum $\mathrm{L}$

\begin{tabular}{|c|c|c|c|c|c|c|c|}
\hline Treatments & $\begin{array}{l}\text { Pre-harvest } \\
\text { total } \mathrm{Pb}(\mathrm{mg} / \\
\mathrm{kg}) \text { in soil }\end{array}$ & $\begin{array}{l}\text { Post-harvest } \\
\text { total } \mathrm{Pb}(\mathrm{mg} / \\
\mathrm{kg}) \text { in soil }\end{array}$ & $\begin{array}{l}\text { Pre-harvest } \\
\text { available } \mathrm{Pb} \\
(\mathrm{mg} / \mathrm{kg}) \text { in soil }\end{array}$ & $\begin{array}{l}\text { Post-harvest } \\
\text { available } \mathrm{Pb} \\
(\mathrm{mg} / \mathrm{kg}) \text { in soil }\end{array}$ & $\begin{array}{l}\text { Reduction \% } \\
\text { in available } \mathrm{Pb} \\
\text { in Soil }\end{array}$ & $\begin{array}{l}\text { Reduction } \\
\% \text { in total } \mathrm{Pb} \\
\text { in soil }\end{array}$ & $\begin{array}{l}\mathrm{Pb} \text { uptake }(\mathrm{mg} / \mathrm{kg} \\
\text { dry biomass) by } C \text {. } \\
\text { indicum } \mathrm{L} .\end{array}$ \\
\hline $\mathrm{N}_{1}$ & $9.6 \pm 0.35$ & $9.4 \pm 0.26$ & $1.55 \pm 0.04$ & $1.26 \pm 0.03$ & 18.71 & 2.08 & $0.41 \pm 0.02$ \\
\hline $\mathrm{N}_{2}$ & $9.6 \pm 0.15$ & $9.4 \pm 0.31$ & $1.56 \pm 0.02$ & $1.27 \pm 0.05$ & 18.59 & 2.08 & $0.41 \pm 0.03$ \\
\hline $\mathrm{N}_{3}$ & $9.6 \pm 0.26$ & $9.3 \pm 0.21$ & $1.56 \pm 0.06$ & $1.27 \pm 0.04$ & 18.59 & 3.12 & $0.42 \pm 0.05$ \\
\hline$T_{1}$ & $9.6 \pm 0.25$ & $9.4 \pm 0.26$ & $1.56 \pm 0.03$ & $1.27 \pm 0.06$ & 18.59 & 2.08 & $0.41 \pm 0.01$ \\
\hline$T_{2}$ & $9.5 \pm 0.15$ & $9.3 \pm 0.20$ & $1.54 \pm 0.04$ & $1.22 \pm 0.02$ & 20.78 & 2.11 & $0.53 \pm 0.04$ \\
\hline$T_{3}$ & $9.6 \pm 0.20$ & $9.2 \pm 0.15$ & $1.54 \pm 0.03$ & $1.19 \pm 0.03$ & 22.73 & 4.17 & $0.61 \pm 0.03$ \\
\hline$T_{4}$ & $9.6 \pm 0.36$ & $9.1 \pm 0.25$ & $1.55 \pm 0.05$ & $1.16 \pm 0.01$ & 25.16 & 5.21 & $0.66 \pm 0.05$ \\
\hline$T_{5}$ & $19.5 \pm 0.40$ & $19 \pm 0.41$ & $1.61 \pm 0.06$ & $1.21 \pm 0.04$ & 24.84 & 2.56 & $2.91 \pm 0.09$ \\
\hline$T_{6}$ & $19.6 \pm 0.62$ & $19 \pm 0.58$ & $1.6 \pm 0.08$ & $1.16 \pm 0.05$ & 27.50 & 3.06 & $3.45 \pm 0.12$ \\
\hline$T_{7}$ & $19.5 \pm 0.26$ & $18.7 \pm 0.46$ & $1.59 \pm 0.05$ & $1.13 \pm 0.03$ & 28.93 & 4.10 & $3.95 \pm 0.28$ \\
\hline$T_{8}$ & $19.6 \pm 0.74$ & $18.5 \pm 0.66$ & $1.61 \pm 0.03$ & $1.12 \pm 0.02$ & 30.43 & 5.61 & $4.45 \pm 0.23$ \\
\hline$T_{9}$ & $29.4 \pm 0.70$ & $28.5 \pm 0.62$ & $1.65 \pm 0.07$ & $1.2 \pm 0.03$ & 27.27 & 3.06 & $6.56 \pm 0.26$ \\
\hline$T_{10}$ & $29.6 \pm 0.97$ & $28.2 \pm 0.89$ & $1.66 \pm 0.06$ & $1.18 \pm 0.05$ & 28.92 & 4.73 & $7.94 \pm 0.21$ \\
\hline$T_{11}$ & $29.6 \pm 1.2$ & $27.9 \pm 1.03$ & $1.67 \pm 0.7$ & $1.15 \pm 0.04$ & 31.14 & 5.74 & $9.42 \pm 0.35$ \\
\hline$T_{12}$ & $29.4 \pm 1.15$ & $27.4 \pm 1.13$ & $1.65 \pm 0.04$ & $1.09 \pm 0.03$ & 33.94 & 6.80 & $10.22 \pm 0.34$ \\
\hline$T_{13}$ & $59.3 \pm 2.06$ & $57.5 \pm 1.47$ & $1.80 \pm 0.09$ & $1.41 \pm 0.07$ & 21.67 & 3.04 & $24.38 \pm 0.25$ \\
\hline$T_{14}$ & $59.4 \pm 2.69$ & $57.3 \pm 1.68$ & $1.79 \pm 0.08$ & $1.36 \pm 0.06$ & 24.02 & 3.54 & $26.42 \pm 0.21$ \\
\hline$T_{15}$ & $59.4 \pm 2.06$ & $56.9 \pm 2.51$ & $1.81 \pm 0.05$ & $1.33 \pm 0.09$ & 26.52 & 4.21 & $27.08 \pm 0.4$ \\
\hline$T_{16}$ & $59.3 \pm 2.25$ & $56.3 \pm 2.26$ & $1.78 \pm 0.03$ & $1.29 \pm 0.05$ & 27.53 & 5.06 & $27.86 \pm 1.06$ \\
\hline
\end{tabular}

\pm values indicate standard error having three replications; refer to Table 2 for treatment symbols 
growing ornamental plants on large centralized scale or suburban to household scale with normal composting methods (Singh et al. 2011) as consumption of organic wastes by earthworms is an ecologically safe method in the natural conversion or stabilization of toxic $\mathrm{Pb}^{+2}$ ions into environmentally less toxic product indirectly through the involvement of microorganisms associated with the vermicompost. However, the differences among control $\left(T_{1}\right)$ and nitrate-only controls $\left(\mathrm{N}_{1}, \mathrm{~N}_{2}, \mathrm{~N}_{3}\right)$ were observed non-significant on influencing total $\mathrm{Pb}(F<0.27)$ and available $\mathrm{Pb}$ $(F<0.093)$ in soil, and $\mathrm{Pb}$ uptake $(F<0.116)$ by the plant.

The present study is an integration of chemical (elemental sulphur), macrobial (earthworms), microbial (bioinoculants associated with vermicompost) and phyto-technological (C. indicum L.) approaches for phyto/bioremediation of a moderately $\mathrm{Pb}$-contaminated soil. However, the present study may not be applicable under highly $\mathrm{Pb}$ contaminated soils especially under severe conditions like petroleum/gas or nuclear production sites. In such conditions, application of resistant and isolated bacteria such as Bacillus sp., Pseudomonas sp., Corynebacterium sp., Staphylococcus sp. and Escherichia coli from $\mathrm{Pb}$-polluted environment have high potential for eliminating this metal from soil to the extent of 89.66, 87.97, 86.64, 64.82 and $60.35 \%$, respectively (Kafilzadeh et al. 2012).

Bioaccumulation, translocation and remediation efficiency

The BF, TF and RR values have been illustrated under the Fig. 5. Mobility of lead from soil solution to plant tissues was significantly $(P<0.0001)$ enhanced by the application of lead from 0 to $50 \mathrm{mg} / \mathrm{kg}$. Further, addition of $\mathrm{S}$ or $\mathrm{VC}$ or both significantly $(P<0.0001)$ boosted the bioaccumulation, translocation and remediation of lead in the experiment among the tested treatments $T_{1}-T_{16}$. However, the differences among control $\left(T_{1}\right)$ and nitrate-only controls $\left(\mathrm{N}_{1}, \mathrm{~N}_{2}, \mathrm{~N}_{3}\right)$ were observed non-significant on influencing BFs $(F<0.112)$, TFs $(F<0.046)$ and RRs $(F=0.093)$ values shown by the plant under the aforesaid treatments.

Comparing the bioaccumulation factors (BF) under treatments $T_{12}-T_{16}$, the trend was observed in the order of $T_{16}>T_{15}>T_{14}>T_{13}>T_{12}$. In general, plants with increased concentrations of lead presented higher BFs. However, the bioaccumulation factors remained below 0.4. Increasing lead levels from 0 to $50 \mathrm{mg} / \mathrm{kg}$ along with $0.8 \mathrm{~g} /$ $\mathrm{kg} \mathrm{S}$ and $6 \mathrm{~g} / \mathrm{kg}$ VC caused 6.3-fold increase in the bioaccumulation factor over the control plots ranging from 0.06 in control to 0.38 in the treatment $T_{16}$. Sulphur individually caused 7.2-fold enhancement in the bioaccumulation factor ranging from 0.05 to 0.36 . The uncontaminated pots showed lower values due to less $\mathrm{Pb}$ concentration in the rhizosphere.

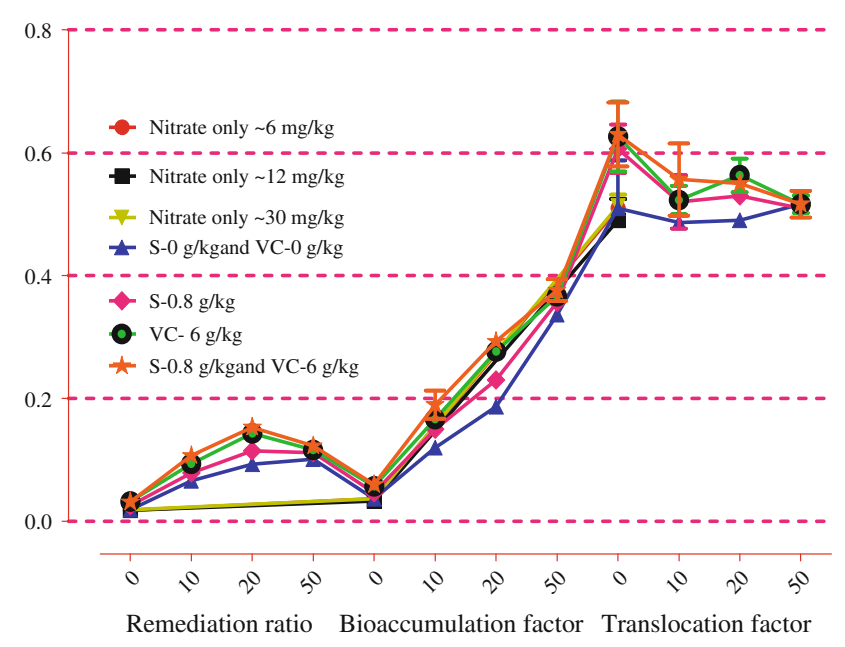

Applied lead $(\mathrm{Pb}$ in $\mathrm{mg} / \mathrm{kg})$

Fig. 5 Bioaccumulation factor (BF), translocation factor (TF) and remediation ratio (RR) shown by $C$. indicum $\mathrm{L}$. from the investigated soil

The higher TFs for $\mathrm{Pb}$ were observed at the lowest $\mathrm{Pb}$ concentrations $(0-10 \mathrm{mg} / \mathrm{kg})$. However, these decreased when $\mathrm{Pb}$ concentrations increased (from 0 to $50 \mathrm{mg} / \mathrm{kg}$ ), showing that at higher concentrations plant shoot tissues restricted more shoot $\mathrm{Pb}$ accumulation. The combinatorial treatment of $\mathrm{S}$ and $\mathrm{VC}\left(T_{4}\right)$ registered the maximum translocation factor (0.63). However, the application of 10 and $20 \mathrm{mg} / \mathrm{kg} \mathrm{Pb}$ without amendments (S and VC) registered the minimum translocation factor (0.49). Comparing the translocation factors (TF) under treatments $T_{12}-T_{16}$, the trend was observed in the order of $T_{12}>T_{16}=$ $T_{13}>T_{15}=T_{14}$. The study indicated that $\mathrm{TF}$ was observed higher in the combinatorial treatments applied with $\mathrm{Pb}$ at $\leq 20 \mathrm{mg} / \mathrm{kg}$ along with sulphur and vermicompost. Nazir et al. (2011) observed almost similar findings for BFs and TFs in several plant species. They observed lower BFs for $\mathrm{Pb}$ in Amaranths virdis (0.32), Cynodon dactylon (0.03), and Partulaca oleracia (0.37) and higher in Chenopodium album (1.10), Cyperus rotundus (1.53), and Sorghum halepense (1.31) as compared to the present study using $C$. indicum L. Similarly, they reported lower TFs for $\mathrm{Pb}$ in Amaranthus virdis (0.34), Achyranthes aspera (0.30), and Malvestrum coromandelianum (0.43) and higher TFs in Brachiaria reptans (0.75), Cannabis sativa (1.03), and Ricinus communis (1.05), as compared to the present findings with Chrysanthemum indicam L (TFs 0.49-0.63).

The uncontaminated pots showed lower RRs due to less $\mathrm{Pb}$ concentration in the rhizosphere of the plant. Comparing the remediation efficiencies (RR) under treatments $T_{12}-T_{16}$, the trend was observed in the order of $T_{12}>T_{16}>$ $T_{15}>T_{14}>T_{13}$. The application of $\mathrm{Pb}$ at $20 \mathrm{mg} / \mathrm{kg}$ along with $\mathrm{S}$ and $\mathrm{VC}\left(T_{12}\right)$ registered the maximum remediation ratio up to 0.153 ; however, the individual application of 
$50 \mathrm{mg} / \mathrm{kg} \mathrm{Pb}\left(T_{13}\right)$ registered comparatively lower remediation ratio than the amended pots (with treatments $T_{14}, T_{15}$ and $T_{16}$ ). It appears that non-amended pots showed lower remediation efficiency $(\leq 0.1)$. However, amended pots under $\mathrm{Pb}$ contamination at $10-50 \mathrm{mg} / \mathrm{kg}$ showed higher remediation efficiency $(>0.1)$. The present study clearly indicates that the efficiency of phytoremediation remains better in the moderately $\mathrm{Pb}$-contaminated soils (Fig. 5) as compared to that of highly $\mathrm{Pb}$-contaminated soils at $50 \mathrm{mg} /$ $\mathrm{kg}$ (Sun et al. 2009). The composite application of S and VC increased the phytoextraction rate of $C$. indicum L. by twofold to ninefolds as compared to the control treatment. Zhuang et al. (2005) reported that addition of $6 \mathrm{~m} \mathrm{~mol} / \mathrm{kg}$ EDTA caused 2-, 13- and 19-fold increase in Pb phytoextraction rate of Vertiveria zizanioides, Rumex hybrid $(\mathrm{K}-1)$ and Viola baoshanensis, showing phytoextraction rate (\%) up to $0.02,0.12$ and 0.18 , respectively. However, Sun et al. (2009) reported $0.05 \% \mathrm{~Pb}$ remediation efficiency of a hyperaccumulator plant, Sedum alfredii H, under EDTAtreated pots at $5 \mathrm{~m} \mathrm{~mol} / \mathrm{kg}$. In the present study, the phytoextraction rate of $C$. indicum $\mathrm{L}$. remained at par with those of Zhuang et al. (2005) and Sun et al. (2009). The higher remediation ratios $(\geq 0.1)$ in 8 treatments (containing either $S$ or VC or both), out of total 19 treatments, proved the potential of plants as well as amendments (S and VC) for enhanced clean-up of soils contaminated with lead in the slightly alkaline soils ( $\mathrm{pH} 7.8$ ).

The study revealed that a lead-contaminated soil cleanup might be achieved through growing non-food crops or ornamental plants like $C$. indicum L., and its remediation potential could be enhanced through the composite application of $\mathrm{S}$ and $\mathrm{VC}$ in the rhizosphere of plants. Meanwhile, environmental clean-up for other heavy metals from other ecosystems will be the future research criteria, which are being investigated by the authors. The strategy for enhanced clean-up of $\mathrm{Pb}$-contaminated soils must be implemented in and around $\mathrm{Pb}$-contaminated soils, especially along the highways, roadways and lead mining areas. Additionally, these areas can be developed as ecotourism through growing ornamental plants to preserve the aesthetic beauty of wasteland as one of the important four components of the environment.

More research is required to unravel the role of microorganisms associated with the vermicompost in the $\mathrm{Pb}$ pathway. The integration of phyto-technology with vermicomposting technology can be a flexible approach to be employed in and around the metal mining areas. Some thermophilic bacteria such as Cupriavidus metallidurans $\mathrm{CH} 34$ have already been isolated from composting reactor for $\mathrm{Pb}$ bioremediation and P-type ATPase (PbrA), and $\mathrm{C}_{55}$-PP phosphatase $(\mathrm{PbrB})$ enzymes have been found responsible for lead resistance. P-type ATPase confers resistance to $\mathrm{Pb}^{2+}$ while $\mathrm{PP}$ phosphatase produces inorganic phosphates for lead precipitation in non-toxic form. Rapid regeneration of $\mathrm{C}_{55} \mathrm{PP}$ produces sufficient amounts of inorganic phosphate for lead sequestration. Similarly, the lead bacterial isolates from the member of the genus Pseudomonas, Bacillus and others have been found capable of eliminating high levels of lead from highly Pb-contaminated soil (Kafilzadeh et al. 2012).

\section{Conclusion}

At lower level (below $20 \mathrm{mg} / \mathrm{kg}$ ), the applied $\mathrm{Pb}$ promoted the growth of $C$. indicum $\mathrm{L}$. but at the higher level (above $20 \mathrm{mg} / \mathrm{kg}$ ), it suppressed the growth of plants including the photosynthetic pigment of the plants. The concentration of $\mathrm{Pb}$ in the tissues followed the order root $>$ shoot $>$ flower. The higher remediation ratio $(>0.1)$ of $C$. indicum $\mathrm{L}$. indicated its phytoremediation potential in Pb-contaminated soils. Addition of $\mathrm{S}$ and VC strengthened its phytoremediation potential in the investigated soils. The phyto-availability of $\mathrm{Pb}$ increased moderately with addition of VC due to supply of complexing agent that interferes with added $\mathrm{Pb}$ fixation. The vermicompost, which comes from domestic origin, has a strong affinity for lead ions. Phytoremediation through ornamental plants minimizes the risk of heavy metals toxicity in biological systems and remains as an innovative, cost-effective, environmental-friendly and sustainable technology especially for the restoration/management of the wastelands/contaminated soils, however, safe disposal of the contaminated plant tissues/parts must be ensured, for harnessing the maximum benefit of this technology. Thus, $C$. indicum $\mathrm{L}$. fulfils the necessary conditions for the cleanup of lead-contaminated soil, and application of S and VC further enhances its phytoremediation potential in the sandy clay loam alluvial soil ( $\mathrm{pH}$ 7.8). Thus, there is great scope of using this ornamental plant for $\mathrm{Pb}$ remediation especially in and around the highways/roadways or glass industries of the metropolitan cities across the globe.

Acknowledgments Authors are grateful to Dr. Alok Lehri, Central Instrumentation Facility Division, National Botanical Research Institute, Lucknow for analysing soil and plant samples for heavy metals by AAS (AAnalyst600, PerkinElmer Inc., MA, USA). The contribution of University Grant Commission (UGC, India) for providing the D Phil Scholarship under UGC Scheme for the degree of Doctor of Philosophy, and the technical/analytical assistance from The National Academy of Sciences India (Allahabad) are gratefully acknowledged. The authors gratefully acknowledge the contribution of reviewers/editors for the peer-review process.

\section{References}

Achal V, Pan X, Zhang D (2012) Bioremediation of strontium (Sr) contaminated aquifer quartz sand based on carbonate 
precipitation induced by $\mathrm{Sr}$ resistant Halomonas sp. Chemosphere 89:764-768

Antoniadis V, Robinson JS, Alloway BJ (2008) Effect of short term pH fluctuations on cadmium, nickel, lead and zinc availability to rye grass in a sewage sludge-amended field. Chemosphere 71:759-764

Barba OAL, Huratado CM, Mata SMC, Ruiz FV, Lopez STM (2006) Application of a UV-Vis detection-HPLC method for a rapid determination of lycopene and beta carotene in vegetables. Food Chem 95:328-336

Bennedsen LR, Krischker A, Jorgensen TH, Sogaard EG (2012) Mobilization of metals during treatment of contaminated soils by modified Fenton's reagent using different chelating agents. J Hazard Mater 199-200:128-134

Bermudez GMA, Jasan R, Pla R, Pignata ML (2012) Heavy metals and trace elements in atmospheric fall-out: their relationship with topsoil and wheat element composition. J Hazard Mater 213-214:447-456

Boonyapookana B, Parkpian P, Techapinyawat S, Delaune RD, Jugsujinda A (2005) Phytoaccumulation of lead by sunflower (Helianthus annus), tobacco (Nicotiana tabacum) and vetiver (Vetiveria zizanioides). J Environ Sci Health A 40:117-137

Chand S, Pandey A, Patra DD (2012) Influence of vermicompost on dry matter yield and uptake of $\mathrm{Ni}$ and $\mathrm{Cd}$ by chamomile (Matricaria chamomilla) in Ni- and Cd- polluted soil. Water Air Soil Pollut 223(5):2257-2262

Chopra SL, Kanwar JS (1999) Analytical agricultural chemistry. Kalyani Publication, New Delhi

Cho-Ruk K, Kurukote J, Supprung P, Vetayasuporn S (2006) Perennial plants in the phytoremediation of lead-contaminated soils. J Biotechnol 5(1):1-4

Dede G, Ozdemir S, Dede OH (2012) Effect of soil amendments on phytoextraction potential of Brassica juncea growing on sewage sludge. Environ Sci Technol 9(3):559-564

Elloumi N, Ben F, Rhouma A, Ben B, Mezghani I, Boukhris M (2007) Cadmium induced growth inhibition and alteration of biochemical parameters in almond seedlings grown in solution culture. Acta Physiol Plant 29:57-62

Fayiga AO, Ma LQ, Cao X, Rathinasabapathi B (2004) Effects of heavy metals on growth and arsenic accumulation in the arsenic hyperaccumulator Pteris vittata L. Environ Pollut 132:289-296

Jarvis MD, Leung DWM (2002) Chelated lead transport in Pinus radiate: an ultastructural study. Environ Exp Bot 48:21-32

Kafilzadeh F, Afrough R, Johari H, Tahery Y (2012) Range determination for resistance/tolerance and growth kinetic of indigenous bacteria isolated from lead contaminated soils near gas stations (Iran). Eur J Exp Biol 2(1):62-69

Kaur G, Singh HP, Batish DR, Kohli RK (2012) Growth, photosynthetic activity and oxidative stress in wheat (Triticum aestivum) after exposure of lead to soil. J Environ Biol 33:265-269

Kayser A, Wenger K, Keller A, Attinger W, Felix HR, Gupta SK (2000) Enhancement of phytoextraction of $\mathrm{Zn}, \mathrm{Cd}$, and $\mathrm{Cu}$ from calcareous soil: the use of NTA and sulphur amendments. Environ Sci Technol 34:1778-1783

Kosobrukhov A, Knyazeva I, Mudrik V (2004) Plantago major plants responses to increase content of lead in soil: growth and photosynthesis. Plant Growth Regul 42:145-151

Kumar C, Mani D (2010) Enrichment and management of heavy metals in sewage-irrigated soil. Lap LAMBERT Acad Publishing, Dudweiler

Lindsay WL, Norvell WA (1978) Development of DTPA soil test for zinc, iron, manganese and copper. Soil Sci Soc Am J 42:421-428

Liu JN, Zhou QX, Sun T, Ma LQ, Wang S (2008) Growth responses of three ornamental plants to $\mathrm{Cd}$ and $\mathrm{Cd}-\mathrm{Pb}$ stress and their metal accumulation characteristics. J Hazard Mater 151:261-267

Madhu G, Rakesh SS, Sengar KG, Kalpana S, Reshu C (2008) Effect of lead on seed germination, seedling growth, chlorophyll content and nitrate reductase activity in Mung bean (Vigna radiata). Res J Phytochem 2(2):61-68

Malkowski E, Kita A, Galas W, Karez W, Michael K (2002) Lead distribution in corn seedlings (Zea mays Linn.) and its effects on growth and the concentration of potassium and calcium. Plant Growth Regul 37:69-76

Mani D, Sharma B, Kumar C, Balak S (2012) Cadmium and lead bioaccumulation during growth stages alters sugar and vitamin $\mathrm{C}$ content in dietary vegetables. Proc Natl Acad Sci India Sect B Biol Sci 82(4):477-488

Mathivanan S, Chidambaram AL, Sundaramoorthy PA, Kalaikandhan $\mathrm{R}$ (2012) Effect of vermicompost on germination and biochemical constituents of groundnut (Arachis hypogaea. L.) seedling. Int J Res Biol Sci 2(2):54-59

Nazir A, Malik RN, Ajaib M, Khan N, Siddiqui MF (2011) Hyperaccumulators of heavy metals of industrial areas of Islamabad and Rawalpindi. Pak J Bot 43(4):1925-1933

Niu Z, Sun L, Sun T, Li Y, Wang H (2007) Evaluation of phytoextracting cadmium and lead by sunflower, ricinus, alfalfa and mustard in hydroponic culture. J Environ Sci 19(8):961-967

Pande P, Chand S, Yadav VK, Anwar M, Patra DD (2007) Influence of chromium with vermicompost on growth and accumulation by Brahmi. Commun Soil Sci Plant Anal 38:2815-2829

Patra M, Bhomik N, Bandopadhyay B, Sharma A (2004) Comparison of mercury, lead and arsenic with respect to genotoxic effect on plant system and the development of genetic tolerance. Environ Exp Bot 52:199-223

Pehlivan E, Özkan AM, Dinç S, Parlayici S (2009) Adsorption of $\mathrm{Cu}^{2+}$ and $\mathrm{Pb}^{2+}$ ion on dolomite powder. J Hazard Mater 167(1-3):1044-1049

Rossato LV, Nicoloso FT, Farias JG, Cargnelluti D, Tabaldi LA, Antes FG, Dressler VL, Morsch VM, Schetinger MRC (2012) Effects of lead on the growth, lead accumulation and physiological responses of Pluchea sagittalis. Ecotoxicology 21(1):111-123

Sandalio LM, Dalurzo HC, Gomez M, Romero-Puertas MC, Del Rio LA (2001) Cadmium-induced changes in the growth and oxidative metabolism of pea plants. J Exp Bot 52:2115-2126

Singh J, Kalamdhad AS (2013) Assessment of bioavailability and leachability of heavy metals during rotary drum composting of green waste (Water hyacinth). Ecol Eng 52:59-69

Singh R, Sarma R, Satyendra K, Gupta R, Patil R (2008) Vermicompost substitution influences growth, physiological disorders, fruit yield and quality of strawberry (Fragaria $\times$ ananassa (Duch.). Bioresource Technol 99:8502-8511

Singh R, Divya S, Awasthi A, Kalra A (2011) Technology for efficient and successful delivery of vermicompost colonized bioinoculants in Pogostemon cablin Benth. World J Microbiol Biotechnol (online: 28 June 2011), doi:10.1007/s11274-0110823-2

Sun YB, Zhou QX, An J, Liu WT, Liu R (2009) Chelator-enhanced phytoextraction of heavy metals from contaminated soil irrigated by industrial wastewater with the hyperaccumulator plant (Sedum alfredii Hance). Geoderma 150:106-112

Sun YB, Zhou QX, Xu YM, Wang L, Liang XF (2011) The role of EDTA on cadmium phytoextraction in a cadmium hyperaccumulator Rorippa globosa. J Environ Chem Ecotoxicol $3(3): 45-51$

Wojcik M, Tukiendorf A (2004) Phytochelatin synthesis and cadmium localization in wild type of Arabidopsis thaliana. Plant Growth Regul 44:71-80

Yang XE, Peng HY, Jiang LY (2005) Phytoremediation of copper from contaminated soil by Elsholtzia splendens as affected by EDTA, citric acid, and compost. Int J Phytoremediation 7:69-83

Zhuang P, Ye ZH, Lan CY, Xie ZW, Shu WS (2005) Chemically assisted phytoextraction of heavy metal contaminated soils using three plants. Plant Soil 276:153-162 